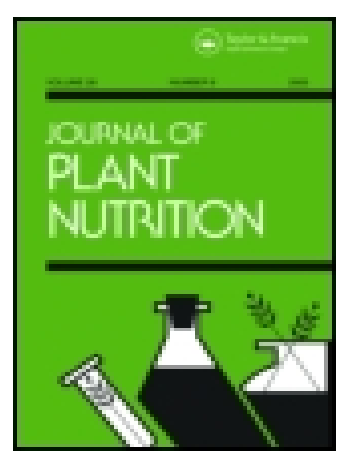

Journal of Plant Nutrition

ISSN: 0190-4167 (Print) 1532-4087 (Online) Journal homepage: http://www.tandfonline.com/loi/lpla20

\title{
Estimating Nutritive Values ofjasminum fruticans L. Plant Species in Northern Rangelands of Golestan Province
}

\section{Seyed Ali Hosseini, Seydeh Zohreh Mirdeilami, Fatemeh Ghilishli \& Mohammad Pessarakli}

To cite this article: Seyed Ali Hosseini, Seydeh Zohreh Mirdeilami, Fatemeh Ghilishli \& Mohammad Pessarakli (2017): Estimating Nutritive Values ofjasminum fruticans L. Plant Species in Northern Rangelands of Golestan Province, Journal of Plant Nutrition, DOI: 10.1080/01904167.2016.1267206

To link to this article: http://dx.doi.org/10.1080/01904167.2016.1267206

Accepted author version posted online: 11 Jan 2017.

Submit your article to this journal $\sqsubset$

Щ Article views: 11

Q View related articles ¿

View Crossmark data 5 


\title{
ACCEPTED MANUSCRIPT
}

\section{Estimating Nutritive Values of Jasminum Fruticans L. Plant Species in Northern \\ Rangelands of Golestan Province}

\author{
Seyed Ali Hosseini, ${ }^{1}$ Seydeh Zohreh Mirdeilami, ${ }^{2}$ Fatemeh Ghilishli ${ }^{3}$ and Mohammad \\ Pessarakli $^{4 *}$ \\ ${ }^{1}$ Research Assistant Professor, Research and Education Center of Agriculture \& Natural \\ Resources, Iran. Email: \\ ${ }^{2}$ Ph.D. Student, Department of Rangeland Management, Gorgan University of Agricultural \\ Sciences \& Natural Resources. \\ ${ }^{3}$ M.S. Student, Department of Rangeland Management, Gorgan University of Agricultural \\ Sciences \& Natural Resources, Iran. \\ ${ }^{4}$ Research Professor and Teaching Faculty- School of Plant Sciences, College of Agriculture and \\ Life Sciences, The University of Arizona.
}

Address Correspondence to Mohammad Pessarakli: pessarak@email.arizona.edu 


\section{ACCEPTED MANUSCRIPT}

\section{ABSTRACT}

Information on different rangeland plants' nutritive values in different parts of plant species and habitats are important in Rangelands Management. Effects of different plant parts (stems and leaves) of the Jasminum fruticans L. plant species on forage quality indicators were investigated in two regions in 2015. Plant samples were collected from Sharlogh Rangelands and cultivated in Research and Education Center of Agricultural and Natural Resources (RECANR) in Iran with completely randomized design with three replications in each plant sample. The plant leaves and stems' samples were oven-dried at $80^{\circ} \mathrm{C}$ for 24 hours, then analyzed for crude protein (CP), crude fiber (CF), dry matter (DM) Ether Extract (EE), Crude Ash (CA), Metabolizable Energy (ME), and mineral elements, including Calcium (Ca) and Phosphorus (P). Results showed that the forage quality indicators in different regions were statistically significant, except for the CA. Also, nutritive values differed significantly $(\mathrm{P}<0.01)$ between different plant parts, except ME parameter. Results also indicated that J. fruticans due to its high tissue $\mathrm{CP}$ content is a valuable source of forage for livestock.

Keywords: Nutrient value, Forage, Jasminum fruticans, Rangeland 


\section{ACCEPTED MANUSCRIPT}

\section{INTRODUCTION}

Range animal productivity and health of livestock depends on the nutritional value of forage available to grazing animals. Therefore, knowing the nutritional value of forage is necessary for the Range Managers to understand the nutritional dynamics of forage to sustain adequate growth and reproduction of animals (Ganskopp \& Bohner, 2001; Richards and Caldwell, 1985), to balance the available forage and the animal's nutrition needs (Dehghani Bidgoli et al., 2012). Woody plants (Fodder trees and shrubs) constitute vital components in livestock productivity, especially in arid and semi-arid zones. The aim of this research is estimating nutritional value of different parts of the shrubby jasmine (Jasminum fruticans L.) plant species in different regions.

Several studies have assessed the nutritional values of forage in natural rangelands (Islam et al., 2003; Nasrullah et al., 2003). Different factors that affect forage nutritive values such as crude protein $(\mathrm{CP})$, acid detergent fiber (ADF), metabolism energy (ME) have been studied by several investigators (Menke and Trlica, 1985; Moore and Biddingscomb, 1994; Orodho et al., 1990). On native rangelands, due to having more feeds to choose from, cattle can adjust their diets and select plants that may be more palatable and nutritious (Hendrickson et al., 1981).

Abusuwar and Ahmed (2010) stated the main feature of browse plants is their high CP and mineral contents. Generally, Calcium $(\mathrm{Ca})$ content is higher than those of other minerals (Backlund and Belskog, 1991). The plants have CP (Holechek, et al., 1983), especially at leaf (Laredo and Minson, 1973; Poppi et al., 1981). Cook and Harris (1950) observed that CP and lignin of grasses on Utah summer range was about $6 \%$ and leaf $\mathrm{CP}$ material $(\sim 12 \%)$ was greater 


\section{ACCEPTED MANUSCRIPT}

than stem CP ( 4\%). The CP and lignin were 12.3 and 20.6 percent in leaf and stem, respectively. Weston et al. (2005) investigated nutritive value properties of Sagebrush-Grass. Their results showed that CP was generally greater for shrubs than grasses. Hussain and Durrani (2009) stated that grasses generally had more dry matter (DM), crude fiber (CF), carbohydrates, neutral detergent fiber (NDF), ADF and hemicelluloses than shrubs, while shrubs were generally high in crude ash (CA), CP, ether extract (EE), nitrogen (N), gross energy (GE), acid detergent lignin (ADL) contents than grasses. Generally DM, CF, NDF, ADF, ADL, carbohydrate and hemicellulose contents increased with the maturity of plants; while ash, CP, EE, N, and ME declined with plants maturity. The nutritive quality of forage decreased with the advancement of phenological growth stages in all analyzed plants. Dehghani Bidgoli and Ranjbarfordoei (2013) stated physiological changes in different plants at various phenological stages are different. The growth stage is effective on plant species quality. As Butler and Bialy (1973) reported the leaves contain high moisture, protein, mineral and low in fiber at early growth stage of forage plants. Quality of pasture affects fibrolytic activity of rumen micro-organisms which may be restricted when poor quality forage is fed (Fondevila et al., 1995). Forage with high digestibility is more intakes (Van Soest, 1994). The forbs and shrubs leaves are more digestible than grass (Short et al., 1974; Milchunas et al., 1978; Wofford and Holechek, 1982). Poor quality forage remains in the stomach of the animal about twice as long as does high quality one. According to Roy (1979) as the level of the roughages in the rations increased, the digestibility of the EE, DM, organic matter and $\mathrm{N}$-free extract decreased and the $\mathrm{CF}$ digestibility increased.

The quality of forage differs at diverse regions. $\mathrm{CP}$ and phosphorus $(\mathrm{P})$ amounts were reported 9 and 0.09 percent, respectively, in Utah shrub lands (Cook et al., 1959), 11 and 0.16 percent in 


\section{ACCEPTED MANUSCRIPT}

grass and desert rangeland of New Mexico (Nelson et al., 1970), 11 and 20 percent in short grassland of arid New Mexico range (Pieper et al., 1978 ‘Cordova and Wallace, 1975), 19 and 0.17 percent in South of Texas (Varner et al., 1979), 8 and 27 percent in Belak Hilz, South of Dacota (Severson, 1982), overall average 11 and 0.17 percent. According to literature review, the amounts of $\mathrm{CP}$ and $\mathrm{P}$ are moderate in shrubs than forbs and grasses.

Several researchers studied nutrient values of forage plants for different range plant species. The research results of Ronald and Rex (1993) showed that the Paspalum distichum have more CP, Sparganium erectum have less $\mathrm{CP}$, and Aeluropus littoralis have CP less than Sparganium erectum plant species. Heshmati et al. (2007) identified Trifolium repens as higher nutritive value with more $\mathrm{CP}$ and Dactylis glomerata as low nutritive value with less $\mathrm{CP}$ among 11 plant species in East of the Golestan Province. Result of research of Ayan et al., 2006 showed that Rumex crispus, Convolvulus arvensis, Plantago lanceolata, Taraxacum officinale, Sangiosorba minor, and Malva neglecta are the most important species for forage uses in the rangeland under this investigation considering the $\mathrm{CP}, \mathrm{CA}$, potassium $(\mathrm{K}), \mathrm{P}$, magnesium $(\mathrm{Mg})$, and $\mathrm{Ca}$ contents. Jung et al. (1996) and Acar and Guncan (2002) stated that high variations were observed in the same species regarding the characters such as CP. Tan and Yolcu (2001) reported that similar weedy species were rich in P, CA, many kinds of minerals in a study on nine wild plant species. More recent researches have revealed that the forage nutritive value of some weed species may be comparable to that of cultivated forages (Tan and Yolcu, 2001; Acar and Guncan, 2002). Dutt et al. (1982) reported that there was no decrease in feeding value of alfalfa and digestibility of forage in the contamination of Medicago sativa and Taraxacum officinale Weber. 


\section{ACCEPTED MANUSCRIPT}

Overall, chemical composition of each plant part should be analyzed for identifying plant species with more forage quality. The introduced nutritive value is useful for planners to select plant species for cultivation and managing-conservation affords. Usually, plant species are selected with high CP, fat, vitamin, carbohydrates, minerals (Lindsey and Ohno, 1999; AlShorepy et al., 2001; Hyder and Sneva, 2003). According to the literature review, type of habitats, plant parts used have effect on quality of forage.

\section{MATERIALS AND METHODS}

\section{Case Study}

This study was conducted in Sharlogh Rangelands around national Golestan park and cultivated at Research and Education Center of Agricultural and Natural Resources (RECANR) Golestan province in northeast of Iran at September 2015. The Sharlogh Rangeland is located at $37^{\circ} 53^{\prime}$ $06^{\prime \prime} \mathrm{N}$ latitude $55^{\circ} 53^{\prime} 21^{\prime \prime}$ E longitude. Mean annual precipitation and temperature are 400 millimeters and $11.5-17.5{ }^{\circ} \mathrm{C}$, respectively. The climate is cold semi-arid with elevation 193 meters above sea level (Figure 1). The dominant vegetation is Juniperus polycarpos, Artemisia sieberi, Astragalus sp. and Festuca ovina (Avarseji, 1995). The RECANR is located at $36^{\circ} 50^{\prime}$ $29^{\prime \prime} \mathrm{N}$ latitude $54^{\circ} 27^{\prime} 28^{\prime \prime} \mathrm{E}$ longitude $41^{\circ} 21^{\prime} \mathrm{N}$ latitude $36^{\circ} 15^{\prime} \mathrm{E}$ longitude. Mean annual precipitation and temperature are 630 millimeters and $17.8{ }^{\circ} \mathrm{C}$, respectively. The climate is moderate semi-moisture with elevation 146 meters above sea level. 


\section{ACCEPTED MANUSCRIPT}

\section{Plant Materials and Sample Collections}

The J. fruticans L. belong to Oleaceae family. This plant is a woody species (Figure 2). This plant is Phanerophytes Life form and Irano-Turanian, Mediterranean, Euro-Siberian Chorotype (Jankju Borzelabad et al., 2011).

Sampling data were collected from three replicated plots of plant parts in different regions. Therefore, 20 plants were harvested for plant parts during the flowering stage in two regions as treatments (Sharlogh and RECARN regions).

\section{Analysis}

The plant materials were dried in an oven at $70-105{ }^{\circ} \mathrm{C}$ for $24-72$ hours. After cooling and weighing, the dried samples were ground. DM percent was calculated (Equation 1).

$\mathrm{DM}=((\mathrm{A}-\mathrm{B}) /(\mathrm{C}-\mathrm{B}))^{*} 100 \quad$ Equation [1]

Where; DM: Dry matter, A: Dry weight, B: Dishes weight and C: Moisture weight.

\section{Crude Protein (CP)}

Measurement of the $\mathrm{CP}$ in this plant species was done by evaluation of the $\mathrm{N}$ content of the plants, assuming that all the proteins in the plants contained $6.25 \%$ nitrogen $(6.25 \% \mathrm{~N})$. The $\mathrm{N}$ was used for protein synthesis at $370-410^{\circ} \mathrm{C}$ for $2-3$ hours. $\mathrm{CP}$ was measured by the Kjeldahl 


\section{ACCEPTED MANUSCRIPT}

technique (AOAC, 1990). Then, the following equation was used to calculate the CP (Equation 2).

$\mathrm{CP}(\%)=(6.25+\% \mathrm{~N}) / \mathrm{A}) . \quad$ Equation [2]

Where; CP: Crude protein, N: Nitrogen content percent, and A: Sample weight $(0.5 \mathrm{~g})$.

\section{Ether Extract (EE)}

The Ether Extract was measured by using 80 CC Eteria (Ethanol, 2-Ethyl-ethanol, 2-Ethyl-ether, Acetone and ect.). The following Equation was used to calculate the EE (Equation 3).

$\mathrm{EE}(\%)=(\mathrm{A}-\mathrm{B}) / \mathrm{C}) * 100 . \quad$ Equation $[3]$

Where; EE: Ether Extract, A: Balloon weight with fat, B: Empty Balloon weight, and Sample weight $(1 \mathrm{~g})$.

\section{Crude Ash (CA)}

CA content was found ashing the plant samples at $550{ }^{\circ} \mathrm{C}$ for 2-3 hours (AOAC 1990) (Equation 4).

$\mathrm{CA}(\%)=(\mathrm{A}-\mathrm{B}) / \mathrm{C}) * 100 . \quad$ Equation $[4]$

Where; CA Crude ash, A: Dishes weight with ash, B: Empty Dishes weight, and Sample weight $(0.2-0.3 \mathrm{~g})$.

\section{Crude Fiber (CF)}




\section{ACCEPTED MANUSCRIPT}

To measure the $\mathrm{CF}$ content of the plants, $1 \mathrm{~g}$ of the ground sample was placed into the glass tubes in the Fibertec. Then, $100 \mathrm{ml}$ ADS (Acid Detergent Solution) was added and boiled for 1 hour. For the preparation of the ADS, $20 \mathrm{~g} \mathrm{BrNH}\left(\mathrm{CH}_{3}\right)_{3}$ (Three methyl bromide) was mixed with 10 milliliters $\mathrm{H}_{2} \mathrm{SO}_{4}$ (Sulfuric acid). Then, the samples were washed with distilled water and acetone in the cold extraction device and placed in the oven at $120^{\circ} \mathrm{C}$ for 2 hours. Afterwards, the samples were put in an electric furnace at $500{ }^{\circ} \mathrm{C}$ for 3 hours. In the electric furnace, all of the samples' cellulose and lignin were burnt and only the minerals were remained. The CF was obtained using the following Equation (Equation 5).

$\mathrm{CF}(\%)=(\mathrm{A}-\mathrm{B}) / \mathrm{C}) * 100 . \quad$ Equation $[5]$

Where; CF: Crude Fiber, A: Initial sample weight, B: Samples weight after burning after weight Samples, and Sample weight (0.3 g).

\section{Metabolisable Energy )ME)}

After the DMD was found, the following formula was used to calculate the metabolisable energy. $\mathrm{ME}=0 / 17 \mathrm{DMD} \%-2$ AOAC (1990).

\section{Mineral Elements}

Mineral elements, including $\mathrm{Ca}$ and $\mathrm{P}$ were measured. The most effective means of determining the type and concentration of specific minerals is to use atomic absorption. The sample to be 


\section{ACCEPTED MANUSCRIPT}

analyzed is normally ashed and then dissolved in an aqueous solution. This solution is placed in the instrument where it is heated to vaporize and atomize the minerals. A beam of radiation is passed through the atomized sample, and the absorption of radiation is measured at specific wavelengths corresponding to the mineral of interest. Information about the type and concentration of minerals present is obtained by measuring the location and intensity of the peaks in the absorption spectra.

\section{Statistical Analysis}

For the comparison of nutrient value plant species t-test was applied. Also the comparison of nutrient value between plant parts one-way analysis of variance (ANOVA), Duncan method was applied.

\section{RESULTS AND DISCUSSION}

The mean nutrient value parameters between at both regions are compared via t-test (Table 1). In this study, region has any significant difference at the nutrient value parameters. Results also showed differences $(\mathrm{P}<0.05)$ between $\mathrm{CA}$ in regions.

The results of the one-way analysis of variance showed significant differences between plant parts of the species for all study parameters $(\mathrm{P}<0.01)$ (Table 2). The mean values of DM and CF parameters of the stems were higher compared with the leaves. The $\mathrm{CP}, \mathrm{CA}, \mathrm{Ca}, \mathrm{P}$, and $\mathrm{EE}$ parameters of the leaves were higher compared to that of the stems. The Ca, P and CA 


\section{ACCEPTED MANUSCRIPT}

parameters of the leaves were similar to that of the total plants. These parameters were different for the stems at the $\mathrm{P}<0.01$ level.

Nutritional value varied $(\mathrm{P}<0.05)$ among regions (Table 1). Results showed that the mean CA of J. fruticans was higher at Sharlogh rangelands (6.5 percent) than RECARN (5.75 percent). This difference is significant at 0.05 probability level. Different researchers have reported $\mathrm{Ca}$ ratios of different regions between 7.6 and 22.2\% (Teutonica and Knorr, 1986; Tan and Yolcu, 2001; Ayan et al., 2006). Shortage of CA caused weakness and increasing mortality of livestock (Holecheck et al., 1983). Therefore, the J. fruticans is better at Sharlogh rangeland for increasing livestock function. Overall, both regions are good sources for providing forage for the livestock.

$\mathrm{Ca} / \mathrm{P}$ contents of the plant species is near 1.95 . The $\mathrm{Ca} / \mathrm{P}$ ratios of $\mathrm{R}$. crispus and $\mathrm{T}$. officinale, were less than 2.00 that are similar to J. fruticans (Ayan et al., 2006). Some researchers (Jacobson et al. 1972, Reid and Jung 1974) have reported that when $\mathrm{Ca} / \mathrm{P}$ ratio is over 2.00, milk fever may be observed in animals, or growing performance and effectiveness of the forageanimal product transformation may decrease. According to the results of Cohen (1975), the $\mathrm{Ca} / \mathrm{P}$ ratio (upto 2) is not limitating factor for livestock production and function. Ruminants resistance for the $\mathrm{Ca} / \mathrm{P}$ ratio higher than 2 is critical for ruminant production.

$\mathrm{Ca}$ contents of the species are $0.33 \%$ (at the Sharlogh rangeland) and $0.37 \%$ (at the

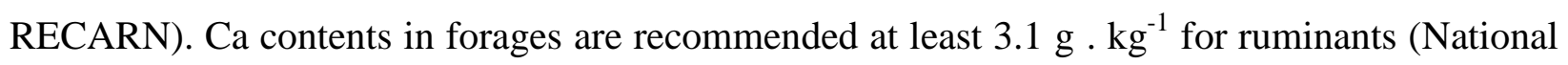
Research Council (NRC), 1984). The values of examined two regions were less than the recommended ones; and those of other species were into the recommended limits (Tan and Yolcu 2001). P contents of the plant species were between $0.17 \%$ (at the Sharlogh rangeland) and $0.19 \%$ (at the RECARN). It is reported that forages for cattle should contain P between 0.17 


\section{ACCEPTED MANUSCRIPT}

and $0.39 \%$ (NRC, 1996) and forages for sheep should have P between 0.16-0.38 percent (NRC 1984). So, these plant species were not into the recommended limits.

The $\mathrm{Ca}, \mathrm{P}$, and CA contents of the leaves are greater than that of the stems. So, the plant leaves are providing needed minerals for the livestock. The mean values of DM, CF, EE, and CP are different between the plant parts for different species at 0.01 probability level. Greater DM and CF were estimated for the stems with 90.54 and $39.22 \%$, respectively. The lowest of these parameters were estimated for the leaves with 34.03 and $17.88 \%$, respectively. This result is similar to that of Hendrickson et al. (1981) that stated intake stem is less by livestock due to high CF and DM content. Dehghani Bidgoli et al. (2012) also stated ADF values in shrubs were higher than that in grass, followed by forbs. However, Ee and CP were greater in leaves (3.23 and 11.08 percent, respectively) than in stems ( 0.73 and $3.74 \%$, respectively). This result is in agreement with Cook and Harris (1950) and Holecheck et al. (1983) results. Cook and Harris (1950) observed that leaf CP content of grasses on Utah summer range ( 12 percent) was greater than that of stem $\mathrm{CP}(\sim 4$ percent $)$.

Overall, the leaves $\mathrm{CP}$ and ME contents of the plant species were greater, while for the stems, the CF was greater. This is due to the maintenance and the strength of the stem tissues. So, nutritive value of the leaf leave is more than stem. This result is similar to that of Ronald and Rex (1993) and Poppi et al. (1981). Plant materials are divided into fibrous and nonfibrous

fractions. In ruminants, fiber fractions that provide energy are important as celluloses and hemicelluloses are easily digestible. The phenolic polymers like lignin are almost indigestible that may hinder carbohydrate digestion (Hussain and Durrani, 2009). 


\section{ACCEPTED MANUSCRIPT}

$\mathrm{CP}$ content of $\mathrm{J}$. fruticans leaves were more than that of D. glomerata, and less than that of Trifolium repens (Heshmati et al., 2007). This appears to be due to climate factors and phenological stages. Changes in the chemical composition of these species showed that plant part of species is the most important factor affecting the forage quality. Therefore, according to these results, in order to improve the rangelands conditions and select a suitable grazing system, the following factor is essential: location of the food reserves in the rangelands' species. The forage quality indicators including all parameters were different in various plant species parts, except for DE. It seems that, the main constituents of the plant structure such as leaf to stem weight ratio, leaves' arrangement, stem length and growth rate determine the quality of the plants.

\section{CONCLUSIONS}

Results indicate that $\mathrm{J}$. fruticans is a valuable source of forage for livestock due to high content of CP in tissues. The poor livestock productivity is partially due to insufficient amount of available good quality forage. In addition, this plant is resistance to fire and grazing intensity (this was observed in the Sharlogh rangeland- Figure 2) and has good growth in the city. This suggests that attention of the range mangers is required to improve the habitat and livestock breeds by cultivating this plant. The managers can plan multiple usage, either development of urban green space or providing forage for the livestock.

Also, it is suggested to estimate the nutritive values of the plant species during the phenological stages in order to meet the nutritional needs of the animals and ensure the regrowth of the rangelands' plant species and determining the grazing time. 


\section{ACCEPTED MANUSCRIPT}

\section{ACKNOWLEDGEMENTS}

The authors thank Golestan Agricultural and Natural Resources Research and Education Center for finance and assistance, Iran.

\section{REFERENCES}

Abusuwar, A.O., and E.O. Ahmed. 2010. Seasonal variability in nutritive value of ruminant diets under open grazing system in the semi-arid rangeland of Sudan (South Darfur State). Agriculture and Biology Journal of North America 1(3): 243-249.

Acar, R., and A. Guncan. 2002. Determination of the morphological characteristic and CP contents of some wild species which can be used as forage crops. Selcuk University, Journal of Agricultural Sciences 16(29): 79-83.

Al-Shorepy, S. A., G. A. Alhandrami, and I. A. Jamali. 2001. Effect of feeding diets containing Seaweed on weight gain and carcass characteristics of indigenous lambs in the United Arab Emirates. Small Rumen Research Journal 4: 283-287

AOAC. 1990. Official Methods of Analysis. Association of Official Agricultural Chemists.: Washington, D.C. pgs 1213.

Avarseji, A. 1995. Investigation vegetation of Mirza Bailou plain and Golestan national park of Almeh [thesis]. Golestan Natural University, Department of Natural Resources, Iran. 129 p. 


\section{ACCEPTED MANUSCRIPT}

Ayan, I., Z. Acar, H. Mut, U. Basaran, and O. Asci. 2006. Morphological, chemical and nutritional properties of forage plants in a natural rangeland in turkey. Bangladesh Journal of Botany 35(2): $133-142$.

Backlund, M., and J. Belskog. 1991. The Role of Trees and Shrubs in Livestock Production in Central Tanzania .A survey of their nutritive value during the dry season .Swedish University of Agricultural Science International Development Centre, Uppsala 24 p.

Butler, G. W., and R. W. Bialy. 1973. Range of protein in the leaf cells Chemistry and Biochemistry of Herbage 1: 67p.

Cohen, R. D. H. 1975. Phosphorus and the grazing ruminant. World review of animal production 11: $27-43$.

Cook, C. W., and L. E. Harris. 1950. The nutritive content of the grazing sheep's diet on the summer and winter ranges of Utah. Utah State University Agricultural Experiment Station Bulletin 342.

Cook, C. W., L. A. Stoddart, and L. E. Harris. 1959. The chemical content in various portions of the current growth of salt-desert shrubs and grasses during winter. Ecology 40: 644-651.

Cordova, F. J., and J. D. Wallace. 1975. Nutritive value of some browse and forb species. Proceedings of American Society of Animal Science 26: 160-162.

Dehghani Bidgoli, R., A. Ranjbarforoei, and D. Akhzari. 2012. Estimation of Nutritive Values of Some Range Species as Indicators for Rangelands Management. Journal of Rangeland Science (2)4: 669-676. 


\section{ACCEPTED MANUSCRIPT}

Dehghani Bidgoli, R., and A. Ranjbarfordoei. 2013. Vegetation types and rangeland species nutritional values and forage quality indicators at various phonological stages. International Journal of Plant Physiology and Biochemistry 5(2): 16-24.

Dutt, T. E., R. G. Harvey, and R. S. Fawcett. 1982. Feed quality of hay containing perennial broadleaf weeds. Agronomy Journal 74: 673-676.

Fondevila, M., C. Castrillo, J. Gassa, and J. A. Guada. 1995. Rumen undegradable dry matter and neutral detergent fiber as ratio indicator in sheep given cereal straw - based diets. Journal of Agricultural Science 125: 145-151.

Ganskopp, D., and D. Bohnert. 2001. Nutritional dynamics of 7 northern Great basin grasses. Journal of Range Management 54: 640-647.

Hendrickson, R. E., D. P. Poppi, and D. J. Minson. 1981. The voluntary intake, digestibility, and retention time by cattle and sheep of stem and leaf fractions of a tropical legume (Lablab purpureus). Australian Journal of Agricultural Research 32:389-398.

Heshmati, G. A., M. Baghani, and O. Bazrafshan. 2007. Comparison of nutritional values of 11 rangeland species in eastern part of Golestan province. Journal of Pajouhesh \& Sazandegi 73: 90-95.

Holechek, J. I., M. Vavra, and R. D. Pieper. 1983. Methods for Determining the Botanical Composition, Similarity and Overlap of Range Herbivore Diets, In National ResearchCouncil/National Academic Science. "Developing Strategies for Rangeland Management Weatview Press, Boulder, Colorado, pp. 425-471.. 


\section{ACCEPTED MANUSCRIPT}

Hussain, F., and M. J. Durrani. 2009. Seasonal availability, palatability and animal preferences of forage plants in Harboi arid rangeland, Kalat, Pakistan. Pakistan Journal of Botany 41(2): 539554.

Hyder, D., and A. Sneva. 2003. Morphological and physiological factors affecting the grazing management of crested wheatgrass. Journal of Crop Science 23: 267-271.

Islam, M. R., C. K. Saha, N. R. Sharkar, M. Jahilil, and M. Hasanuzzamam. 2003. Effect of variety on proportion of botanical fraction and nutritive value of different Napier grass (Pennisetum puporeum) and relationship between botanical fraction and nutritive value. Asian-Australian Journal of Animal Science 16: 177-188.

Jacobson, D. R., R. W. Hemken, R. S. Button, and R. H. Hatton. 1972. Mineral nutrition, calcium, phosphorus, magnesium and potassium interrelationships. Journal of Dairy Science 55: 935-944.

Jankju Borzelabad, M., F. Mellati, and Z. Atashgahi. 2011. Flora, Life Form and Chorology of Winter and Rural Range Plants in the Northern Khorasan Province, Iran. Journal of Rangeland Science 1(4): 269-284.

Jung, G. A., J. A. Shaffer, G. A. Varga, and J. R. Everhart. 1996. Performance of grasslands Puna chicory at different management levels. Agronomy Journal 88: 104-111.

Laredo, M. A., and D. J. Minson. 1973. The voluntary intake, digestibility, and retention time by sheep of leaf and stem fractions of five grasses. Australian Journal of Agricultural Research $24: 875-888$

Lindsey, Z. W. and M. Ohno. 1999. World seaweed utilization: An end of century summery. Journal of Applied Phycology 11: 369-376. 


\section{ACCEPTED MANUSCRIPT}

Menke, J., and Trlica, J. 1985. Carbohydrate reserves, phonology and growth cycles of nine Colorado range species. Journal of Range Management 34: 269-277.

Milchunas, D. G., M. I. Dyer, O. C. Wallmo, and D. E. Johnson. 1978. In Vivo/In Vitro Relationships of Colorado Mule Deer Forage. Colorado Division of Wildlife Special Report, No. 43. Fort Collins.

Moore, R., F. Biddingscomb. 1994. The effects of grazing on grassland. Journal of Agricultural Science 23:221-235.

Nasrullah, N. M., R. Akashi and O. Kawamura. 2003. Nutritive evaluation of forage plants in South Sulaweshi, Indonesia. Asian-Australian Journal of Animal Science 16: 693-701.

Nelson, A. B., C. H. Herbel, and H. M. Jackson. 1970. Chemical Composition of Forage Species Grazed By Cattle on an Arid New Mexico Range. New Mexico Agricultural Experimental Station Bulletin. . No. 561.

NRC. 1984. Nutrient Requirements of Domestic Animals. Nutrient requirements of beef cattle. $6^{\text {th }}$ Revised edn. National Academy of Sciences of the United States of America. Washington DC.

NRC. 1996. Nutrient Requirements of Beef Cattle. $7^{\text {th }}$ Revised edn. National Academy of Sciences of the United States of America. Washington DC.

Orodho, A. B., M. J. Trlica. and C. D. Bonham. 1990. Long-term heavy grazing effects on soil and vegetation in the Four Corners Region. Journal of Southwestern Naturalist 35(1): 9-14.

Pieper, R. D., A. B. Nelson, G. S. Smith, E. E. Parker, E. J. Boggino, and S. L. Hatch. 1978. Chemical Composition and Digestibility of Important Range Grass Species in South-Central New Mexico. New Mexico State University, Agricultural Experiment Station Bulletin. No. 662. 


\section{ACCEPTED MANUSCRIPT}

Poppi, D. P., D. J. Minson, and J. H. Ternouth. 1981. Studies of cattle and sheep eating leaf and stem fractions of grasses. I. The voluntary intake, digestibility, and retention time in the reticulorumen. Australian Journal of Agricultural Research 32:99-108.

Reid, R. L., and G. A. Jung. 1974. Effects of elements other than nitrogen on the nutritive value of forage. pp. 395-435. In D.A. Mays (ed.) Forage Fertilization, American Society of Agronomy, Madison, WI.

Richards, J. H., and M. M. Caldwell. 1985. Soluble carbohydrates, concur-rent photosynthesis and efficiency in re-growth following defoliation: A field study with Agropyron species. Journal of Applied Ecology 22(3): 907-920.

Ronald L. B., and E. R. Rex. 1993. Forages for cattle: New methods of determining energy content and evaluating heat damage. Agricultural Pollution G3150, University of Missouri, Department of Animal Sciences, Columbia.

Roy, A. C. 1979. Profitable Pasture Management. The Interstate Printers and Publishers, New York, pp. 230Meirion, Thomas, Ranson, S.L., and Richardson, J.A. 1973. The rate of increase in dry matter. Plant physiology 5th. Ed. 273 P.

Severson, K. E. 1982. Production and nutritive value of aspen understory, Black Hills. Journal of Range Management 35: 786-790.

Short, H. L., R. M. Blair, and C. A. Segelquist. 1974. Fiber composition and forage digestibility by small ruminants. Journal of Wildlife Management 38:197-202.

Tan, M., and H. Yolcu. 2001. The nutrition value of some wild plants as a forage crops. Türkiye 4. Field Crops Congress, pp. 199-204. 


\section{ACCEPTED MANUSCRIPT}

Teutonica, R. A., and D. Knorr. 1986. Amaranth. Composition, properties and applications of a rediscovered food crop. Food Technology Journal 39(4): 49-60.

Van Soest, P. J. 1994. Nutritional Ecology of the Ruminant. Comstock Publishing Associates, 488p.

Varner, L. W., L. H. Blankenship, and G. W. Lynch. 1979. Seasonal changes in nutritive value of deer food plants in south Texas. Proc. Annu. Conf. Southeast. Association of Fish and Wildlife Agencies. 31: 99-105.

Weston, T. R., R. A. Olson, V. Nayigihugu, S. L. Lake, J. D. Derner, G. E. Schuman, and B. W. Hess. 2005. Characteristics and potential nutritive value of sagebrush-grassland vegetation collected from sites continuously grazed, rested for one year and one year post-disturbance. Proceedings, Western Section, American Society of Animal Science 56: 1-4.

Wofford, H., and J. L. Holechek. 1982. Influence of grind size on four-and forty-eight hour in vitro digestibility. Proceedings of American Society of Animal Science 33: 261-263. 


\section{ACCEPTED MANUSCRIPT}

FIGURE 1. The locations of the studied area in Iran (A) and Golestan Province (B)

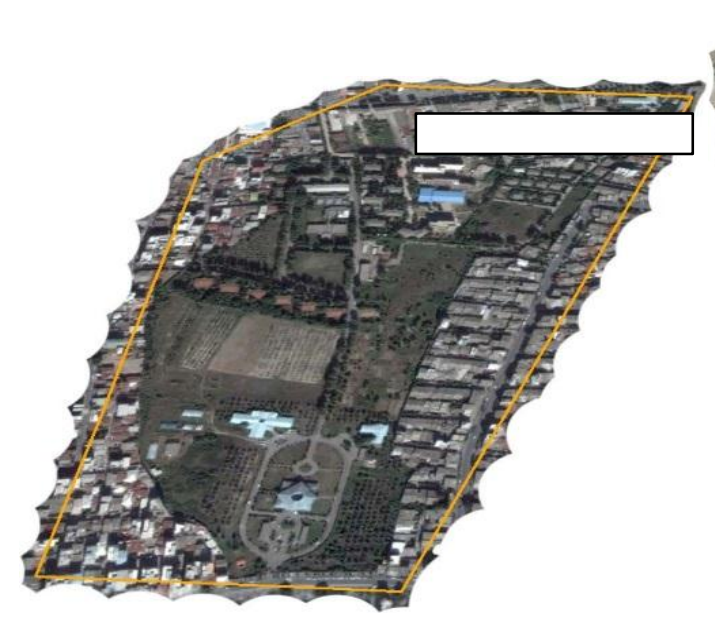

A
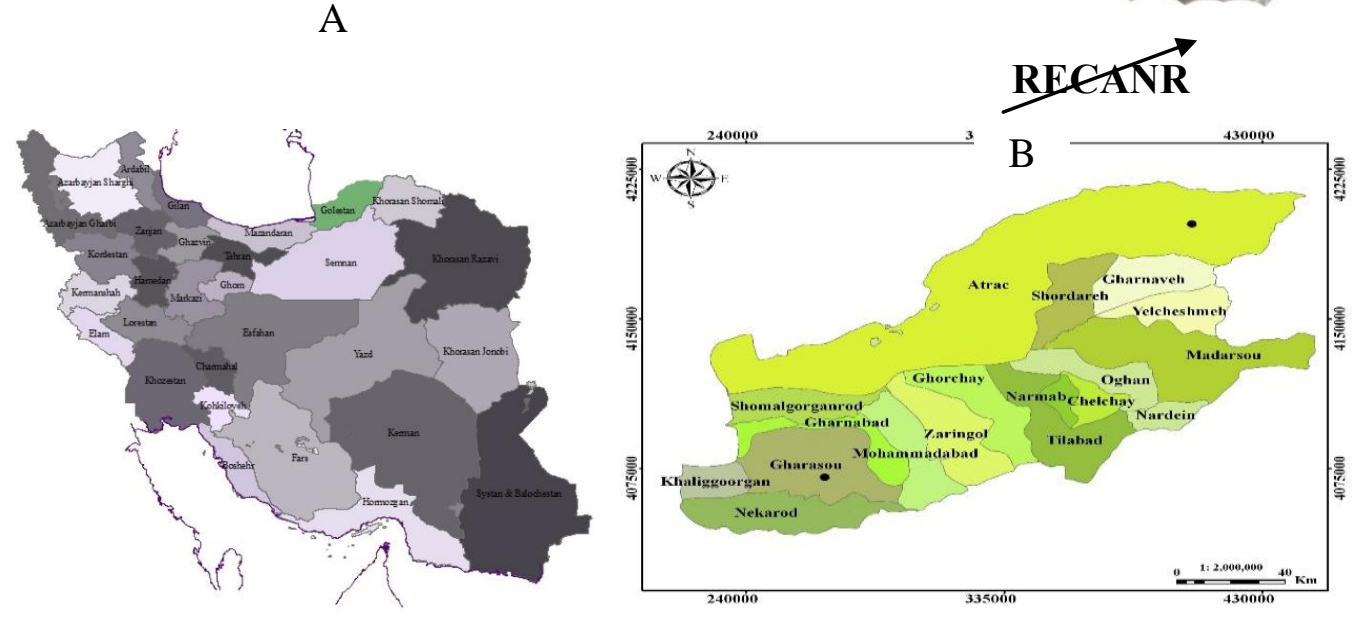

RECARN
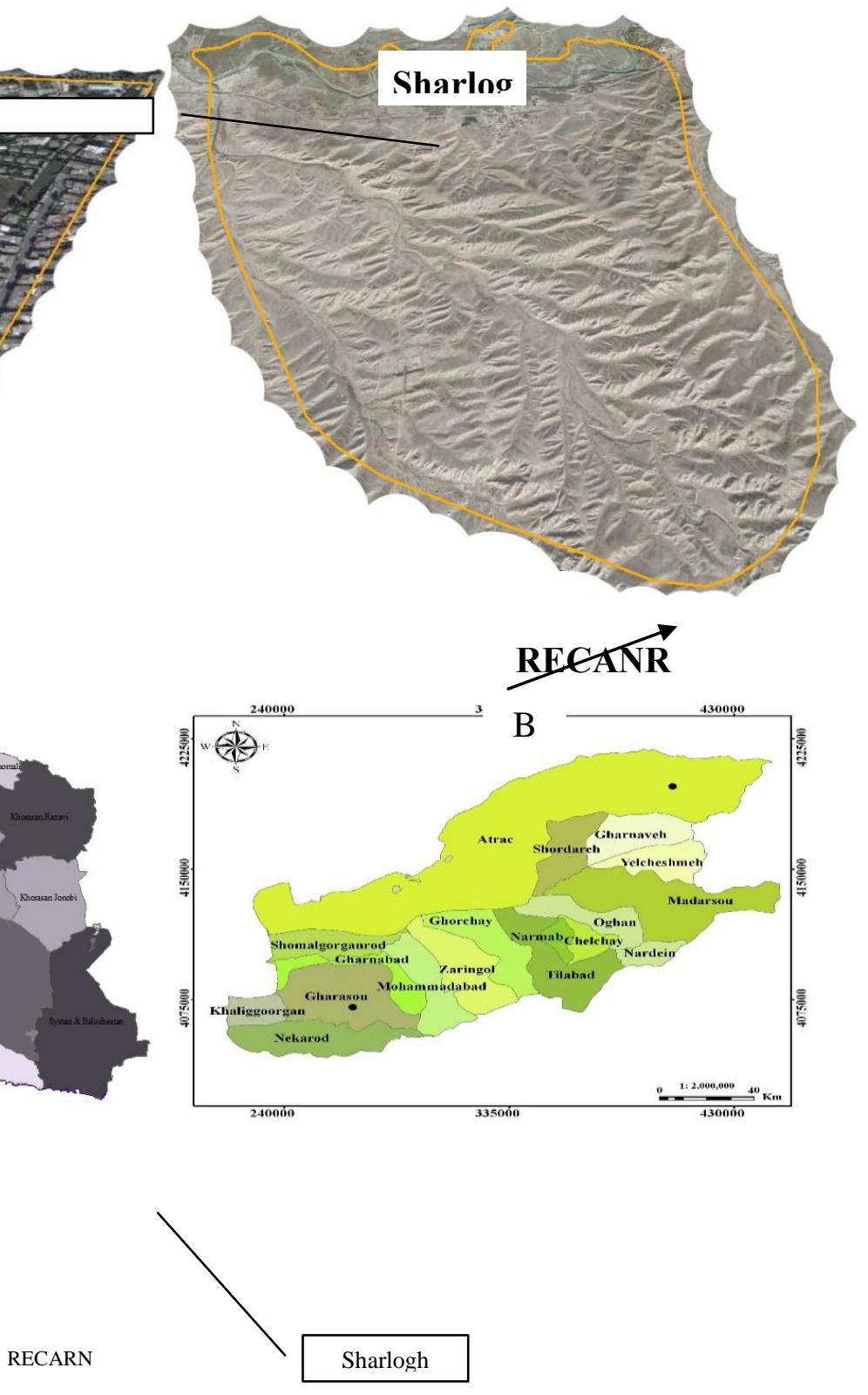


\section{ACCEPTED MANUSCRIPT}

FIGURE 2. The plant species of Jasminum fruticans L.

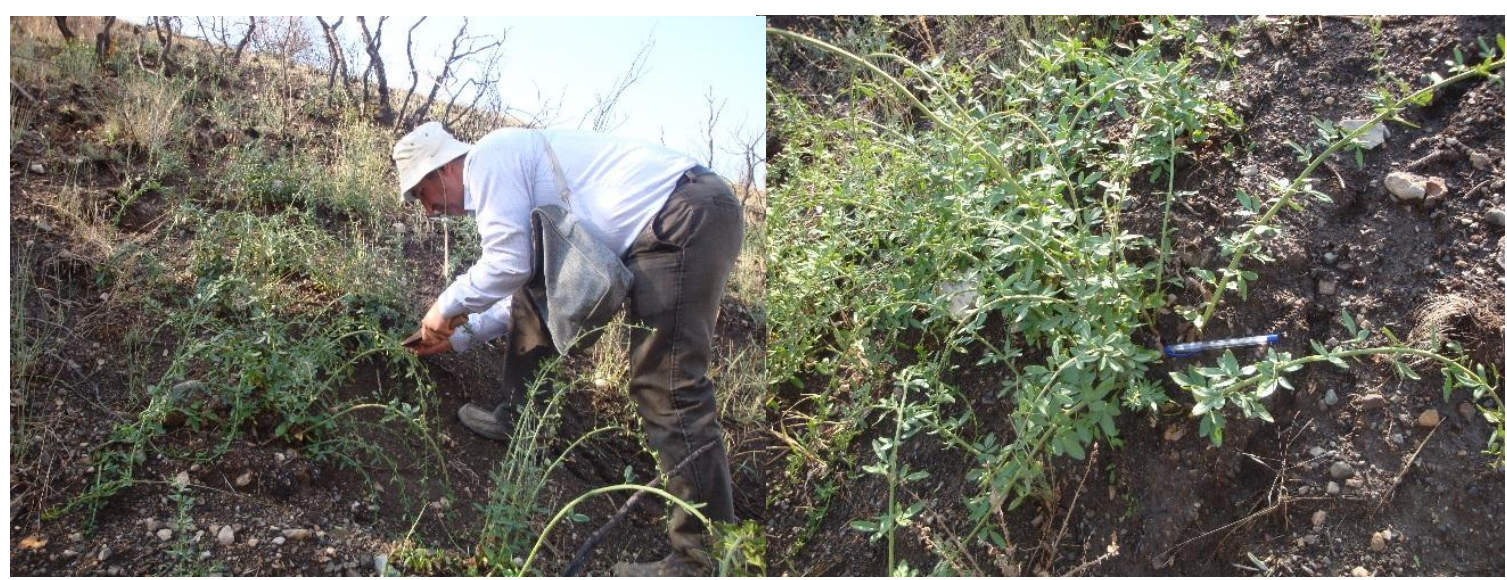




\section{ACCEPTED MANUSCRIPT}

TABLE 1. Comparing of nutrient value parameters between region treatments

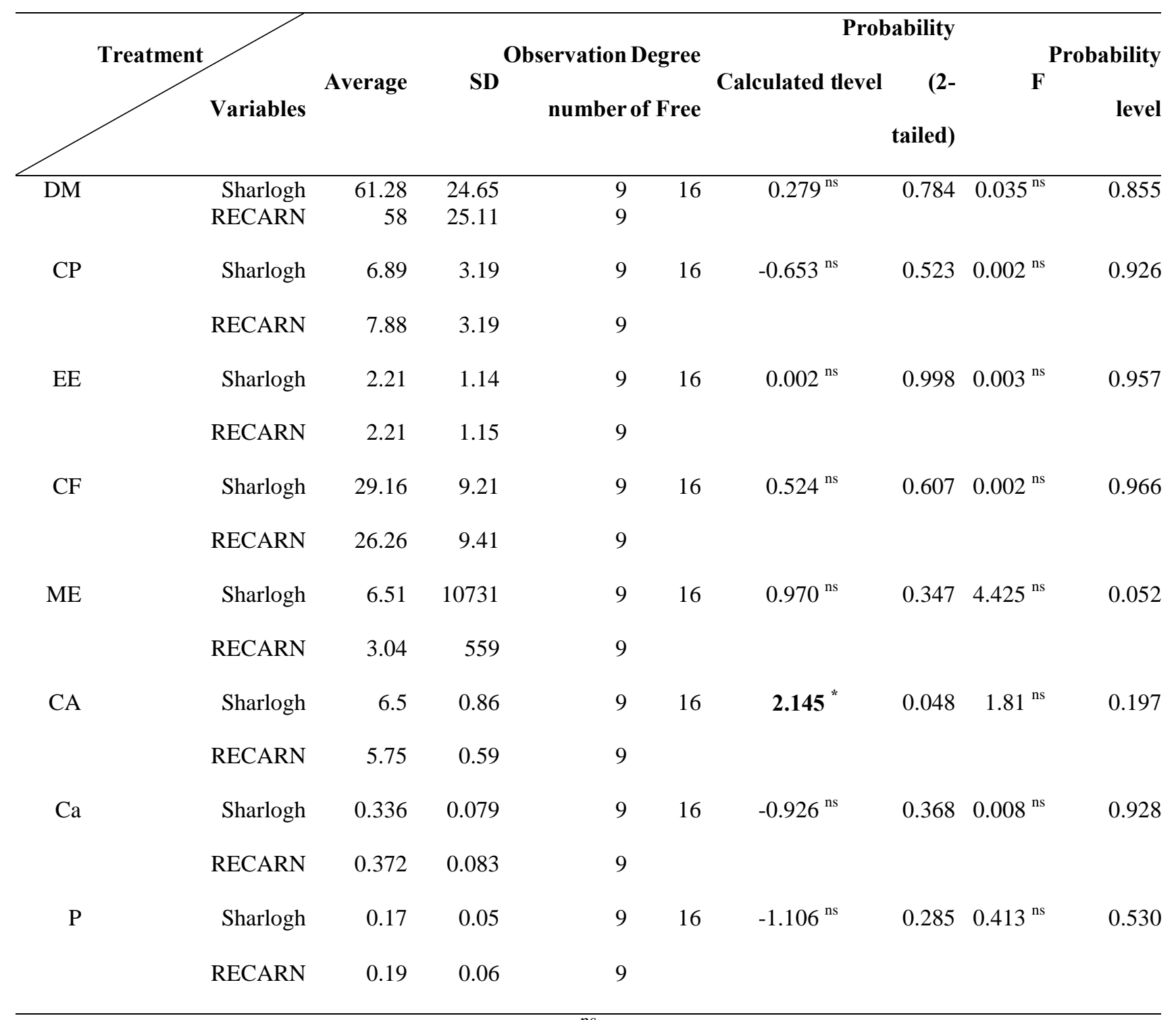

* Significant difference at 5 percent level, ${ }^{\text {ns }}$ : no significant difference 


\section{ACCEPTED MANUSCRIPT}

TABLE 2. Comparison of the nutritive value parameters between the plant parts

\section{Degree}

Parameter Treatment of

MS
The average of parameters

F Sig

between plant parts

Free

Total Leave Stem

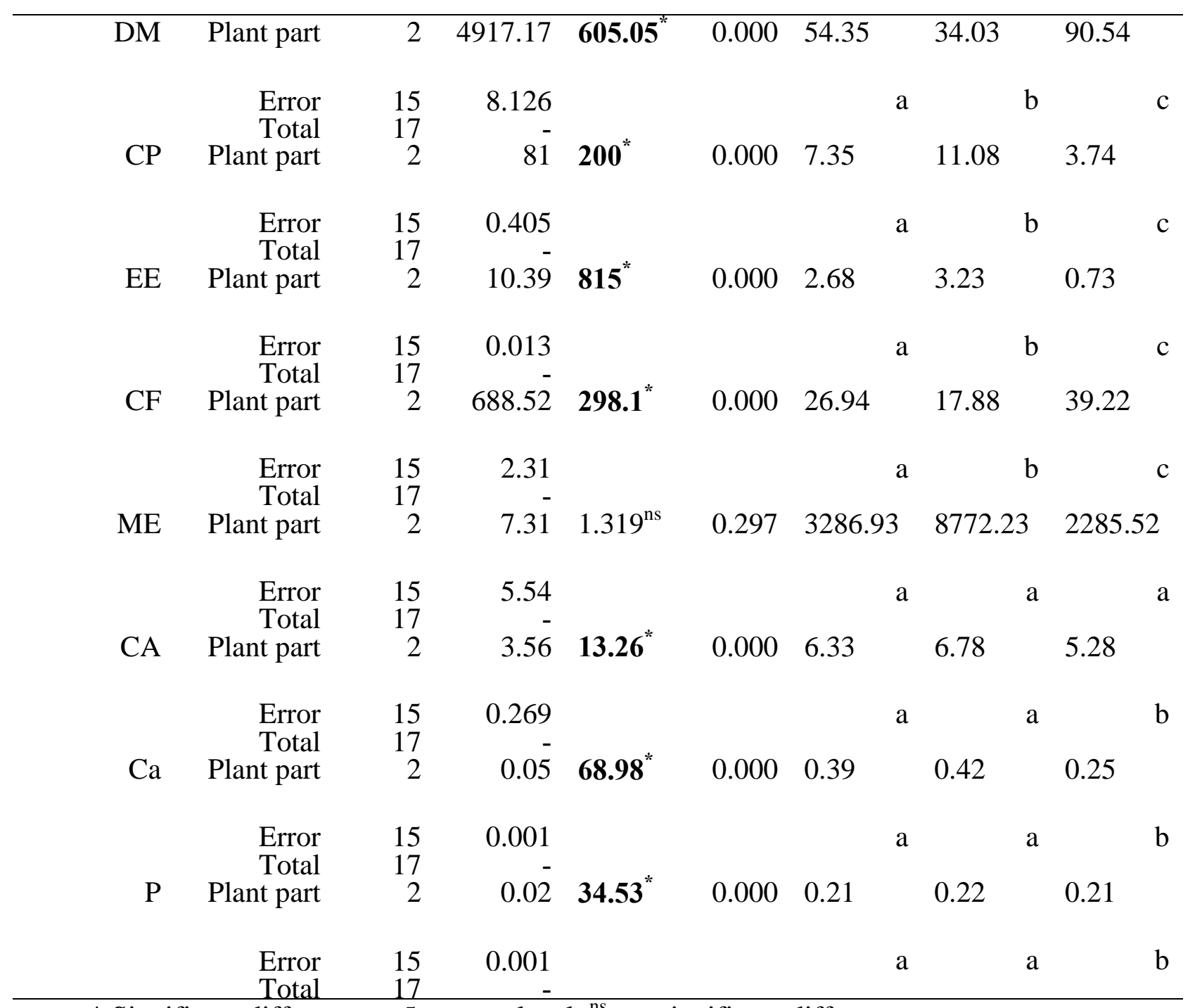

* Significant difference at 5 percent level, ${ }^{\text {ns }}$ : no significant difference 